\title{
Some Old Problems in a Modern Guise
}

$\mathrm{L}$ UMLEY V. WAGNER, ${ }^{1}$ like most novel doctrines, has drawn after it a chain of consequences. Not the least interesting of these are found when it crosses the path of the administrative rules of equitable relief, and in particular the so-called "mutuality rule." Litigation over the contracts of baseball players, a form of pastime recently engaging the interest of the devotees of this sport almost as much as the actual game itself, has given rise to a number of interesting questions of this type..$^{2}$ The fundamental character of some of the questions raised may justify a review of these cases even for those who are not accustomed to rely upon legal periodicals for their sporting information.

The American game of baseball long since became one of the most profitable of commercial enterprises. Organization of its business management became so complete and efficient that, in the year 1913, practically all of the professional ball clubs of the United States were component members of a single system known as "Organized Baseball," governed by what is called the "national agreement," and solving its own problems and difficulties through a "national commission" consisting of some five men. These clubs are grouped in some forty separate leagues known as "major" and

1 (1852), 1 DeG. M. \& G. 604, 50 Eng. Ch. Rep. 466.

2 Thirteen cases have been officially reported and as this article is written a further opinion has been filed in the case of Cincinnati Exposition Co. v. Marsans (1914), 216 Fed. 269, but is not yet available; while a solution on a large scale of the various questions involved is hanging fire in the court of Judge $K$. M. Landis of the United States District Court for the Northern District of Illinois. These thirteen cases are: Philadelphia Ball Club v. Hallman (1881), 8 Pa. Co. Ct. 57, 20 Phila. 276; Harrisburg Baseball Club v. Athletic Ass'n. (1881), $8 \mathrm{~Pa}$. Co. Ct. 337; Columbus Baseball Club v. Reiley (1891), 11 Ohio Dec. 272,25 Wkly. Law Bul. 385; Allegheny Baseball Club v. Bennett (1882), 14 Fed. 257; Metropolitan Exhibition Co. v. Ward (1890), 9 N. Y. Supp. 779, 24 Abb. N. C. 393; Metropolitan Exhibition Co. v. Ewing (1890), 42 Fed. 198, 7 L. R. A. 381; Baltimore Baseball Club \& Ex. Co. v. Pickett (1894), 78 Md. 375, 28 Atl. 279, 22 L. R. A. 690; Philadelphia Ball Club v. Lajoie (1902), 202 Pa. 210, 51 At1. 973; Brooklyn Baseball Club v. McGuire (1902), 116 Fed. 782; Weeghman v. Killifer (1914), 215 Fed. 168, 289; Cincinnati Exhibition Co. v. Johnson (1914), 190 Ill. App. 630; American League Baseball Club v. Chase (1914), 86 Misc. Rep. 44, 149 N. Y. Supp. 6; Cincinnati Exhibition Co. v. Marsans (1914), 216 Fed. 269. 
"minor," but are mutually bound together by stringent contracts regulating both business and playing competition. The ten thousand players are bound in turn to the several clubs by contracts most drastic in character, the principal terms of which, excepting as to salary, are prescribed by the "national agreement," and the breach of any of these terms by the player renders him ineligible to any of the teams operating under the system. A more coinplete and effective inonopoly could scarcely be contrived. These incidents are justified by the organization as ultimately advantageous to the players as well as to the club owners, upon the grounds that they insure stability, public confidence, improved conditions of service and increased salaries. In the recent case of American League Baseball Club of Chicago v. Chase, ${ }^{8}$ however, Bissell, J., although rather unnecessarily, said that the "national agreement" while not within the Sherman Anti-Trust Law, constituted a monopoly in contravention of the common law and was therefore illegal. In I9I3 a competing major league was organized and its attempt to secure from "Organized Baseball" many of the players previously under contract with its leagues has resulted in a number of litigations. With a single exception," these suits have been brought in equity to prevent a player from performing for a rival arganization.

It has long been a familiar rule that equity will not specifically enforce an affirnative contract calling for personal services. ${ }^{5}$ Lumley v. Wagner, however, though avowedly rested on previous decisions, is deemed to have introduced the doctrine which is now generally established, that where an express covenant is embodied in the contract prohibiting the contracting party from giving his services elsewhere, equity will enjoin a breach of such negative covenant, although it cannot specifically enforce the affirmative parts of the defendant's agreement. This of course is enforcing only a part of the contract, but it usually, though by no means necessarily, ${ }^{8}$ has the result of inducing a performance of the defendant's affirmative covenants. Lumley v. Wagner itself, while involving the services of a famous singer, contains no indication

8 (1914), 86 Misc. Rep. 441, 149 N. Y. Supp. 6.

* Baltimore Baseball Club, etc. Co. v. Pickett (1894), 78 Md. 375, 28 Atl. 279, 22 I. R. A. 690.

S Clarke v. Price (1819), 2 Wil. Ch. 157.

- It did not have this effect in Lumley v. Wagner. See Lumley v. Gye. (1853), 2 El. \& Bl. 216. 
that the doctrine is to be confined to cases of service of a unique or extraordinary character, nor do later English decisions. Mr. Pomeroy, in his work on Specific Performance, ${ }^{7}$ said :

"It is plain that the principle on which the rule rests is the same as that which applies to agreements for the purchase of lands or of chattels having a unique character and value. The damages for the breach of such contracts cannot be estimated with any certainty, and the employer cannot by means of any damages purchase the same service in the labor market."

There are many American decisions subsequent to this text, to the effect that the doctrine of Lumley v. Wagner will, therefore, not be applied unless the services contracted for are of a type that is special, unique or extraordinary. 8 In Metropolitan Exhibition Company v. Ward, ${ }^{9}$ it was said that there was no reason to distinguish in the application of the rule "between an actor of great histrionic ability and a professional baseball player of peculiar fitness and skill to fill a particular position." It has since been assumed that playing baseball may involve service of the requisite unique, or extraordinary type, and the decisions are rested upon Metropolitan Exhibition Company v. Ward. A number of American cases citing each other and the foregoing statement from $M r$. Pomeroy, ${ }^{10}$ have entered upon an inquiry as to the particular abilities of the particular defendant in his chosen field, ${ }^{11}$ and have refused an mjunction unless he was so peculiarly talented as to be an exceptional performer, and unless his services were therefore incapable of ready replacement. In Columbus Baseball Club v. Reiley, ${ }^{12}$ in Harrisburg Baseball Club v. Athletic Association, ${ }^{13}$ and

72 d ed., p. 31.

8 It will be found upon an examination of these cases that they were rested either upon this statement of Mr. Pomeroy, who cited no case as authority, or upon cases which held nothing of the sort. The limitation is, however, a natural and probably correct one upon the reasons given by Mr. Pomeroy, but it is an unusual instance of a doctrine founded upon a text statement.

9 (1890), 9 N. Y. Supp. 779, 24 Abb. N. C. 393.

10 For example, Strobridge Lithographing Co. v. Crane (1890), 58 Hun, 611, 12 N. Y. Supp. 898; Carter v. Ferguson (1890), 58 Hun, 569, 12 N. Y. Supp. 580; Universal Talking Machine Co. v. English (1901), 34 Misc. Rep. 342, 69 N. Y. Supp. 813; Burney v. Ryle (1893), 91 Ga. 701, 17 S. E. 986; Cort v. Lassard (1884), 18 Ore. 221, 22 Pac. 1054.

${ }_{11}$ Thus in Cort v. Lassard (1884), 18 Ore. 221, 22 Pac. 1054, the court carefully inquired into the exact merits of a given acrobatic performance to see whether it was superior, medium, or poor, and reached the conclusion that the defendant "did only a fair act," and hence could not be enjoined.

12 (1891), 11 Ohio Dec. 272, 25 Wkly. Law Bul. 385.

13 (1881), 8 Pa. Co. Ct. 337. 
in Brooklyn Baseball Club v. McGuire, ${ }^{14}$ injunctions were denied, apparently in part upon the ground that the abilities of the particular player were not of stellar character nor such that he could not be satisfactorily substituted for. In Philadelphia Ball Club v. Lajoie, ${ }^{15}$ the court said that it was not necessary to show that the defendant's services were of such a character as to render it impossible to replace him, but that it was sufficient to show "that the same service could not easily be obtained from others." The court viewed Lajoie as a player, if not "the sun in the baseball firmament, certainly a bright particular star," and granted an injunction. Since that case no baseball player has been permanently enjoined, and no question as to whether a given player was not skilful enough to bring him within the rule has been raised. It may well be questioned whether the courts have not gone too far in making the test of the applicability of the rule of Lumley $v$. Wagner to depend upon individual fitness and skill rather than upon the type of service called for by the contract. The personal test seems a most difficult one. Particularly is this true in such a line of effort as baseball, where permanence of club organization is sought for and wherein abilities are developed and ripened gradually, so that the player's chief value may lie in the promise he shows for future usefulness rather than in his past or present achievement. In land contracts it is not important that an adequate or even exact measure of dainages exists. The remedy at law is deemed inadequate because the subject matter is land. In service contracts involving skill the personal equation element seems as important as the individuality of land is in that type of contract.

In Montague v. Flockton, ${ }^{16}$ it was held that the negative covenant need not be express but might in a proper case be implied. It is understood that this doctrine was abandoned in England in Whitwood Chemical Company v. Hardman,13 but Montague v. Flockton has had some following in the United States. ${ }^{18}$ This doctrine has not been applied as yet in any case involving a baseball player, an express negative covenant being a part of the standard contract. ${ }^{18}$

14 (1902), 116 Fed. 782.

16 (1902), $202 \mathrm{~Pa} .210,51$ Atl. 973.

16 (1873), 16 Eq. 189.

17 [1891]' 2 Ch. 416.

182 Illinois Law Review, 217.

10 In Allegheny Baseball Club v. Bennett (1882), 14 Fed. 257, the 
The failure of club owners to secure injunctive relief has been complete, except in the case of Philadelphia Ball Club v. Lajoie, supra. The difficulty has arisen almost entirely froin the so-called "reserve" and "release" clauses of the player's contract. These were inserted with a view of securing a maximuin control over the player's services, and of according him the minimun of enforceable rights.

In Metropolitan Exhibition Company v. Ward, supra, the "reserve" clause read:

"It is further understood and agreed that the club shall have the right to reserve the player for the next season ensuing .... upon the following conditions .... he shall not be reserved at a salary less than that mentioned in the twentieth paragraph $[\$ 3,000]$ except by his consent."

The court considered itself unable to ascertain the salary or the terms and conditions of service intended for the ensuing season, and refused specific performance on the ground of indefiniteness and uncertainty. It offered some objection to the option character of the agreement, and further asserted that if the contract stipulated for was one upon the terms of the preceding year, it would become automatically perpetual because the reserve clause would itself be renewed. This last objection must be deeined more fanciful than real. An agreement to renew a note or lease contemplates but a single renewal, and not a renewal in perpetuam by a renewal of the renewal clause itself. It is difficult to see why an option upon a man's services, founded upon adequate consideration, should not be equally as enforceable as an option upon tangible property. In the similar case of a rental of premises with an option to the lessee to purchase during the term, the consideration of the rental to be paid during the term renders enforceable and irrevocable the option to purchase. ${ }^{20}$ No apportionment of the consideration is necessary. ${ }^{2 x}$ In the later baseball contracts out of excess of caution an apportionment of consideration is made in the proportions of seventy-five and twenty-five per cent between the service to be furnished in a given year, and the option for the succeeding year. ${ }^{22}$ This seems to have a moral rather than a substantial legal effect.

court refused an injunction without giving an opinion. There was no express negative covenant but many other questions were raised:

20 Laffan v. Naglee (1858), 9 Cal. 662; Hall v. Center (1870), 40 Cal. 63.

21 McCormick v. Stephany (1898), 57 N. J. Eq. 257, 41 Atl. 840.

22 That such apportionment is a subterfuge is evident from the fact 
While, of course, equity will not specifically enforce a contract which is not definite in its terms, it may be doubted whether the arrangement in Metropulitan Exhibition Company v. Ward did not have sufficient definiteness. It would not be an extreme position to inply a continuance of the old terms and conditions of service, ${ }^{23}$ nor to say that an agreement to work for a salary "not less than $\$ 3,000$ " is an agreement to work "for $\$ 3,000$ unless the other party chooses to pay more." 24 In Metropolitan Exhibition Company v. Ewing, ${ }^{25}$ however, the court, examining the "reserve" clause in the light of the "national agreement," held that its true meaning was only that the player thereby agreed to give the reserving club a prior and exclusive right as against other clubs operating under the agreement, to enter into a contract with him, if player and club could inutually agree, and was not intended to give the club a complete option upon his services. If such be the somewhat extraordinary intention of the parties, of course it follows that this is only "a contract to make a contract if the parties could agree," and therefore no contract at all. The latest form of standard contract seems drawn with the purpose of negativing any such extraordinary intention. In American League Baseball Club of Chicago v. Chase, supra, the "reserve" clause read:

"ro. The player will at the option of the club enter into a contract for the succeeding season upon all the terms and conditions of this contract, save as to clauses $\mathrm{I}$ and ro [salary and reserve] .... and the salary to be paid the player in the event of such renewal shall be the same as the total compensation provided for the player in clause I hereof unless it be increased or decreased by mutual agreement."

The court in that case offered no specific criticism of this clause, and it is difficult to see how it can be said that the renewal agreement foregoing is not in itself definite, clear, founded on consideration and capable of specific enforcement. ${ }^{28}$

that the new contract is to be for the same total consideration as the former one, but is not to contain the renewal clause, for which twentyfive per cent of the consideration in the old contract is stated to be given. The omission of the renewal clause is evidently in deference to the rather fanciful objection found in the Ward case, that the contract otherwise would become automatically perpetual.

${ }_{28}$ The court took this position in Metropolitan Exhibition Co. v. Ewing (1890), 42 Fed. 198, 7 L. R. A. 381.

14.

24 See very similarly Williams v. Miller (1885), 68 Cal. 290, 6 Pac.

25 (1890), 42 Fed. 198.

28 The "reserve" clause in Weeghman v. Killifer (1914), 215 Fed. 168, 
Perhaps the most interesting question presented by the contract is that arising from the "release" clause. This in the customary form is:

"It is further understood and agreed that the party of the first part may, at any time after the beginning and prior to the completion of the period of this contract, give the party of the second part ten days' written notice to end and determine all its liabilities and obligations under this contract, in which event all liabilities and obligations undertaken by said party of the first part, in this contract, shall at once cease and determine at the expiration of said ten days; the said party of the second part shall thereupon be also freed and discharged from obligation to render service to said party of the first part. If such notice be given to the party of the second part while 'abroad' with the club, he shall be entitled to his necessary traveling expenses to the city of ...." [home city].

It will thus be observed that while it is sought to obtain an option upon the player's services for a second season, he inay be released even during the first season upon ten days' notice. ${ }^{27}$ In Metropolitan Exhibition Company v. Ward, Weeghman v. Killifer, American League Baseball Club of Chicago v. Chase, and Cincinnati Exhibition Company v. Johnson, it was held that this clause of itself would defeat a specific performance of the negative covenant upon the ground that it prevented the contract from having "mutuality." There is no opinion in the Johnson ${ }^{28}$ case, and the view is but briefly expressed in Weeghman v. Killifer. In the Ward case, the court, quoting from Fry on Specific Performance, says:

"A contract that is sought to be specifically enforced must be mutual both as to the remedy and to the obligation. A party not bound by the agreement itself has no right to call upon a court of equity to enforce specific performance by expressing his willingness in his bill to perform his part of the engagement. His right to the aid of the court does not de-

289 , seems, on the other hand, almost inspired to merit the criticism of being a "contract to make a contract if the parties can agree," as it provides that the salary shall be such as the parties shall determine. See Ridgway v. Wharton (1857), 6 H. L. Cas. 238, 10 Eng. Rep. R. 1287; Fairplay School v. O'Neal (1891), 127 Ind. 95, 26 N. E. 686.

${ }_{27}$ In Baltimore Baseball Club \& Ex. Co. v. Pickett (1894), 78 Md. 375,28 Atl. 279,22 L. R. A. 690 , the court, on the ground that it contradicted the written contract, refused to admit evidence of a custom that all players' contracts were terminable on ten days' notice. The specific clause to that effect was therefore inserted.

28 It is understood that the court, in Cincinnati Exhibition Co. v. Marsans (1914), 216 Fed. 269 , has subsequently vacated a temporary injunction upon the same ground. 
pend upon his subsequent offer to perform the contract, on his part, but upon its original obligatory character."

In American League Baseball Club of Chicago v. Chase, the court said:

"Tle absolute lack of mutuality both of obligation and of remedy in this contract, would prevent a court of equity from making it the basis of equitable relief by injunction or otherwise. The negative covenant under such circumstances is without a consideration to support it, and is unenforceable by injunction. No court can be called upon to do a vain and useless thing, for if the court issues an injunction the person in whose favor the injunction may issue might render nugatory the action of the court by terminating the contract, and second, that the contract being unilateral, lacks mutuality in that the employer having the right to terminate the contract, the employee is remediless when such right is exercised. He can neither secure specific performance of the contract in an action against the employer in a court of equity, nor damages in an action at law."

Both courts confuse non-mutuality in the securing of performance of the contract, and non-mutuality of obligation. Much of the language quoted from the Chase case is open to serious criticisin, whatever be the correctness of the decision. ${ }^{28}$

The terms "unilateral contract" and "mutuality" are very loosely used by most courts. The former term has been used to denominate the situation (I) Where an offer has been made and the offeree has the proposition under advisement; ${ }^{30}$ (2) Where an offer lias been made for an indefinite quantity of some commodity and the aceeptance is in general terms specifying no definite amount, ${ }^{31}$ or where one of the parties explicitly reserves the right to cancel the contract at any time; ${ }^{82}$ (3) Where mutual promises have been exchanged, but one promise for some reason apart from offer and acceptance, is not completely or legally binding, as for exainple, a promise induced by fraud, a promise of an infant, a verbal promise within the Statute of Frauds, and the like; ${ }^{3 s}$ (4) Wliere the promisor lias made a prom-

29 In Weeghman v. Killifer (1914), 215 Fed. 168, Sessions, J., makes the extraordinary statement that "a contract exists but if broken by either party the other is remediless because the courts are helpless either to enforce its performance or to award damages for its breach." ${ }^{80}$ Cooke v. Oxley (1790), 3 Term Rep. 653, 100 Eng. Rep. R. 785.

81 Laclede Construction Co. v. Tudor Iron Works (1902), 169 Mo. 137,69 S. W. 384.

${ }_{82}$ Barrett v. Dean (1866), 21 Iowa, 423.

38 Compare Banbury v. Arnold (1891), 91 Cal. 606, 27 Pac. 934, where the court said that a married woman's unacknowledged contract 
ise in return for an act that has been performed; ${ }^{34}$ (5). Where obligatory mutual promises have been exchanged, but where by reason of some administrative equitable rule specific performance cannot be compelled of one side of the contract. ${ }^{35}$ The fourth is the only one of the five instances that is clearly both a contract and "unilateral." The first case is obviously merely an offer; the second either a standing offer ${ }^{38}$ or a rejected offer $;{ }^{37}$ the third a rescindable or disaffirmable bilateral contract, and the fifth, a valid bilateral contract.

The term "mutuality" seems to have meanings corresponding to all of these situations. In the first situation, the phrase, "lack of mutuality" means that there has been no acceptance tendered and hence that neither party is bound; ${ }^{38}$ in the second that there has been an illusory acceptance or one in name and not in fact, and that neither party is bound; in the third that a bilateral contract has failed to be mutually obligatory because of some supervening rule other than those of offer and acceptance, and that one or both parties have a defense to its enforcement both in law and in equity ${ }^{39}$ in the fourth, that the contract is not one of mutual promises but of a promise for an act. The first two are never contracts; the third is a defective contract; the fourth is a valid contract. In each one of these cases the mutuality involved is mutuality of obligation. In the first two there is no contract because there is no such mutuality; in the third one side may be able to hold the other both in law and in equity, despite the absence of such mutuality; and in the fourth the absence of mutuality of obligation is immaterial because it is not an ingredient of a contract consisting of a promise accepted by the doing of an act. An offer of a reward is the typical case. At no stage in a contract of the fourth type will both parties be bound. Either the transaction is in the stage of mere offer or of completed performance. The offeree in a true unilateral contract is never suable because he can never be in default. Never having promised to do anything, there

for the sale of her land did not have mutuality; and Bloom v. Hazard (1894), 104 Cal. 310, 37 Pac. 1037.

34 Harriman on Contracts, 2d ed., §621; Nevada Bank v. Steinmetz (1383), 64 Cal. 301, 30 Pac. 970.

35 American League of Baseball of Chicago v. Chase (1914), 86

Misc. Rep. 441,149 N. Y. Supp. 6.

36 Great Northern Ry. Co. v. Witham (1873), 9 C. P. 16.

37 Chicago \& G. E. Ry. Co. v. Dane (1870), 43 N. Y. 240.

38 Compare, Anson v. Townsend (1887), 73 Cal. 415, 15 Pac. 49.

39 Banbury v. Arnold, supra, n. 7. 
is nothing he can fail in doing. Lack of "mutuality" can never be a defense by the offeror upon such a contract either in law or in equity, for the offeree can never go into court without having completely performed.

The ball player's contract is not "unilateral" or lacking "mutuality" in any of these four senses. The offer has been accepted, and accepted in definite terms; there is no right to rescind in toto for some fault inherent in the agreement; and the case is one of a promise for a promise and not of a promise for an act. Consideration on each side is the promise of the other party. The player promises his services for a season, etc., and the club promises payment therefor, subject to the right to terminate the contractual relation by the operation of a condition subsequent under the reserved right to discharge on ten days' notice. The contract is, until the happening of the condition subsequent, mutually obligatory, that is a bilateral contract. To say that a contract is not a contract because it may cease to be binding for the future upon the happening of some subsequent event is to ignore settled distinctions. A lease terminable upon the happening of a future event is none the less a lease until the occurrence of the event, nor is it material that the event is within the control of one of the parties. If it could be brought about at any tine to take effect instantly, it could be urged that the obligation was illusory rather than real, and that the case would be like the second class of cases hitherto noted. But it is not so here. The club is bound in any event for ten days, and if this means that it must pay the player his salary for ten days ${ }^{\mathbf{0}}$ there is an obligation that the club cannot escape. Certainly an irrevocable offer to furnish any quantity of tons of iron up to three hundred and sixty-five would be legally accepted to the extent of ten tons by an agreement to take that many. The situation is the same if the offeree agreed to take three hundrd and sixtyfive, with the privilege of returning three hundred and fifty-five if he chose. The law has never undertaken to see that both the parties have made a good bargain. In the absence of fraud, law courts have never concerned themselves with the quantum of consideration. ${ }^{41}$ A promise to employ for ten days is therefore un-

40 It is not perfectly clear that the club, if it chose to terminate a contract before the playing season began, would have to pay salary for that period. The contract seems ambiguous in this respect.

11 See the familiar cases of Wolford v. Powers (1884), 85 Ind. 294, 44 Am. Rep. 16; Bainbridge v. Firmstone (1838), 8 Ad. \& E. 743; 
doubtedly a good consideration for a promise to work for ten, coupled with an option for three hundred and fifty-five more, or as many more as there are in a season. It is not perceived how the case is changed by casting the agreement in the form of a promise for three hundred and sixty-five days, subject to a condition subsequent as to all but ten.

The court in American League Baseball Club of Chicago v. Chase was, therefore, in error when it said that there was "an absolute lack of mutuality of obligation," that "the negative covenant is without consideration to support it," and that the contract was "unilateral." In fact the contract was bilateral; the negative covenant, though perhaps specifically unenforceable, was supported by a good legal consideration; there was mutuality of obligation until the contract should be rightfully terminated, and it would be actionable, so far as the release clause alone is concerned, by either party in a court of law upon any failure of performance according to its terms. Whether the agreement is rendered unfair within the meaning of the equitable rule or encounters any other rules peculiar to equity is a different matter.

Properly speaking it is only in the fifth classification mentioned above ${ }^{42}$ that "mutuality" has any peculiar equitable signification. In the first two classes there can obviously be no specific performance of a contract because there is no contract. In the third there is no reason why, if the person who has a right to avoid the contract does not care to do so, the case should not stand as though he never had had the right, and hence no reason why he cannot, if the subject matter is of equitable cognizance, secure equitable as well as legal aid. Thus, the insane or drunken contracting party, the one who has been induced by misrepresentation, etc., having rights at law and having ratified the contract or waived his objections by an appeal to the courts, can secure specific performance from the other party. ${ }^{43}$ This is merely an illustration that the contract is not void but only voidable, and when not avoided is wholly valid in a court of equity as well as in a court of law. So the plaintiff who has not signed a memorandum for a contract within the Statute of Frauds can sue the defendant who has, ${ }^{44}$ for by filing his bill for

Brooks v. Ball (1820), 18 Johns. 337; and Merchant v. O'Rourke (1900), 11 Iowa, 351,28 N. W. 759 .

42 Supra, n. 35.

433 Columbia Law Review, 1.

$4+$ Vassault v. Edwards (1872), 43 Cal. 458. 
specific performance he supplies the missing memorandum. In all these instances the defect which might have been urged in avoidance of the contract has been waived or cured and the contract is both bilateral and of complete mutual obligation. Of course had the other party first begun suit he could have had no relief in law or in equity. As an infant cannot in any way make the contract non-disaffirmable while he remains an infant, he cannot get specific performance during his infancy ${ }^{\text {ts }}$ on a principle presently to be noted. In the fourth class equity should grant relief, for the defendant has already secured full performance from the plaintiff and the fact that there was no contract between them until that time is utterly without logical bearing. ${ }^{40}$

It is a somewhat curious fact that a system of law should exist among civilized peoples where the customary remedy for breach of contract is by way of damages rather than by way of compelling the party to do what he promises to do. One approaching the question without knowledge of the fact would naturally suppose that the balance would be the other way. Of course among people as jealous of personal liberty as the Anglo Saxons, it is natural that there should be some hesitation about compelling a man to perform services of a personal character, but the explanation other than this is largely historical. It has grown out of the formalistic ideas found in early procedure, the comparatively late development of Chancery as a system, and the relations of law and equity courts during that period. Thus it was the exceptional case wherein an actual performance by the contracting party was compelled. The case came in only as a part of equity's extraordinary jurisdiction and the suitor was allowed relief only as a special favor. A court thus sparing of its aid and viewing a resort to it as an extraordinary sort of affair, would naturally feel also a hesitancy about undertaking to adjust difficulties between two contending parties where the whole subject matter was such that it could not render effective decrees determining the entire controversy. An affirmative aspect of this attitude led it to extend its jurisdiction into granting a money decree as an imcident to other equitable relief, and to grant a vendor specific performance agamst a vendee who was ouly to pay money. However, the primciple cut both ways. In its negative aspect it prevented relief in some cases wherein the

46 Flight v. Bolland (1828), 4 Russ. 298.

4 Howe v. Watson (1901), 179 Mass. 30, 60 N. E. 415. 
subject matter otherwise was of equitable cognizance. These reasons were not as compelling where the aid sought was merely to preserve the status quo, and injunctions to restrain a party while rights were litigated at law were frequent. But where equity was asked to take compulsory affirmative action against one who had broken or who had threatened a breach of his contract, it saw that to do justice it must either keep hands off or compel a performance by both sides. ${ }^{47}$ Either one theory of relief or another had to be adopted-either that of actual performance or of damages for non-performance. To mix the two would not be performance according to the terms of the contract. Performance by one side would not be just unless the party performing was insured a performance by the other. To compel the defendant specifically to give up that which he had agreed to give, when the court could not be certain that he would get in return specifically that which the plaintiff had promised him, would not be compelling specific performance of the contract, but only of a part of it. Part performance might be more unjust than none at all. This attitude was not arbitrary but perfectly sound and logical. Overlooking the real reason behind this attitude, and attempting to translate it into a phrase, courts and lawyers came to say that "equity will not interfere unless the remedy in equity is mutual," 48 or as Pomeroy puts it, 49 "the remedial right to specific performance must be mutual." This statement of the rule did not account for a number of patent facts. (I) Equity always compelled specific performance when the plaintiff had completely performed on his part. ${ }^{50}$ (2) Equity would not allow a defendant to set up his own fault as a bar to relief against him, because it deemed a plaintiff who asked its assistance to have waived defenses of that sort. ${ }^{51}$ (3) Equity would not permit a defendant to set up that the plaintiff might originally have avoided the contract, if he had in fact chosen to confirm and abide by it. ${ }^{52}$ In such cases equity was assured that if it ordered a specific performance by the defendant he would equally secure a com-

47 Compare, Cooper v. Pena (1863), 21 Cal. 403; Blanton v. Ky. Dist. \& Warehouse Co. (1902), 120 Fed. 318.

48 Cooper v. Pena (1863), 21 Cal. 403.

$492 \mathrm{~d}$ ed., p. 229.

50 Ballard v. Carr (1874), 48 Cal. 74; Howard v. Throckmorton (1874), 48 Cal. 482; King v. Gildersleeve (1889), 79 Cal. 504, 21 Pac. 961; Thurber v. Meves (1897), 119 Cal. 35, 50 Pac. 1063. n. 48 .

51 Marshall v. Caldwell (1871), 41 Cal. 611.

52 Ex parte Lacey (1802), 6 Ves. Jr. 625; Cooper v. Pena, supra, 
plete performance from the plaintiff, and entire justice would be done. To require the plaintiff's case against the defendant to be decided by the merits of the defendant's case agaimst the plamtiff had the plaintiff rather than the defendant been in default, would be a very illogical process. But a principle that equity would give its affirmative aid to the plaintiff only if it could do complete justice by assuring performance by the plaintiff also, is a very understandable and intelligent attitude.53 The current way of stating the rule also ignored the striking fact that the only case which originally could completely supply its conditions was a case of exchange of lands or of two subject matters each of equitable cognizance, and that a simple case of a sale of land for money did not fall within its literal terms.

The attitude that equity would not undertake specific performance unless it could do complete justice would seem at first sight to require that it would not restrain the brcach of a negative covenant in a defendant's contract in any case where it could not also specifically enforce the performance of the defendant's positive covenants. However, this is a somewhat different matter. If the plaintiff is satisfied with what relief he obtains it is hardly necessary for the court to object that it cannot give him all that he is entitled to. The practical effect too is usually to induce full performance by the defendant, although Lord St. Leonards, in Lumley v. Wagner, expressly disclains the influence of such a result. Lumley v. Wagner, however, does violate the assertions of Fry ${ }^{54}$ and Pomeroy, that there must be mutuality of equitable remedy, and that of Fry, that it must exist at the time of the making of the contract. One of the duties of Lumley was to maintain an opera house and an opera troupe to enable Miss Wagner to perform in

58 There are many California cases illustrating the principle. A contract whereby plaintiff is to give services for land is not specifically enforceable even though the plaintiff tenders performance. Cooper v. Pena, supra n. 48; Stanton v. Singleton (1899), $126 \mathrm{Cal}$. 657, 59 Pac. 146; Wakeham v. Barker (1889), 82 Cal. 46, 22 Pac. 1131; Lattin v. Hazard (1891), 91 Cal. 87, 27 Pac. 515; O'Brien v. Perry (1900), 130 Cal. 526, 62 Pac. 927; Moore v. Tuohy (1904), 142 Cal. 342, 75 Pac. 896; Los Angeles Co. v. Occidental Oil Co. (1904), $144 \mathrm{Cal}$. 528, 78 Pac. 25; Pacific El. R. R. Co. v. Campbell-Johnson (1908), 153 Cal. 106, 94 Pac. 623. If the plaintiff has performed, however, specific performance will be enforced, note 50 supra. An option contract is specifically, enforceable, for by the exercise of the option, both obligation and remedy are mutual. Iaffan v. Naglee, supra, n. 20; Hall v. Center, supra, n. 20; Calanchini v. Branstetter (1890), 84 Cal. 249, 24 Pac. 149; Sayward v. Houghton (1898), 119 Cal. 545, 51 Pac. 853.

\& 5 th ed., $\$ 460$. 
the part she contracted for. The opportunity to appear before a London audience was also a real part of the consideration moving to her. Even if the court could compel Lumley to pay the part of the salary stipulated for and earned in case Miss Wagner were to perform pursuant to this injunction, it had originally no independent jurisdiction to compel him merely to pay money, not even after full voluntary performance by Miss Wagner. That was a matter purely of legal cognizance. Nor could a court of equity have compelled Lumley to maintain an opera troupe and opera house to enable the performance by Miss Wagner of the terms of her contract, either when the contract was drawn or at any time thereafter, even after the decree.

Dean Ames, ${ }^{, 5}$ pointing out eight exceptions to the rule as stated by Fry, but for some reason not noting the added exception of Lumley v. Wagner, has suggested a preferable phrasing of the "mutuality" rule as follows:

"Equity will not compel specific performance by a defendant, if after performance the common law remedy of damages would be his sole security for the performance of the plaintiff's side of the contract." ${ }^{66}$

This statement is far more accurate and certainly comprehends the great bulk of adjudications. But even this most careful phrasing, if we accept Lumley v. Wagner as law, is not true in one case $^{57}$ that can readily be put, and it may be doubted whether in spirit it recognizes the decision in Lumley $\mathrm{v}$. Wagner itself.

In that case Miss Wagner on November Ist, contracted to sing in London between April Ist and July Ist following. It is not perfectly clear from the report of the case that her covenant forbade her singing elsewhere in London between the dates of November Ist and April Ist, but we can readily suppose a case where the covenant would be so drawn. In fact the baseball player's contract is exactly a case of that sort. The suit of Lumley $v$. Wagner was brought on April 29, that is, after the time of performance by Lumley also had arrived. However, let us assume in the case pro-

553 Columbia Law Review, 1.

so Thus we have a fifth and sixth sense of "mutuality," i. e. "mutuality of remedy" and "mutuality of performance."

57 Unless the word "complete" be understood before the word "performance;" and in that event, the rule being negative in form, would not cover cases of partial continuous performance. It is as fair to insert the word "any" before "specific" as it is to insert "complete" before "performance." 
posed that the singer in the interim between November Ist and April Ist began singing for a rival. The injury to the manager who relies on the novelty of the performance and the vogue of the singer, is practically the same whether the breach occurs before or during the time for her appearance in his theater. There is no reason to suppose that an injunction would not issue in his favor at any time prior to April Ist, as well as after April Ist. If so, the singer would be compelled by injunction to perform the negative covenants from November Ist to April Ist, without the slightest assurance that when April ist arrived she would be permitted by the plaintiff to make the public appearance for which she and the plaintiff had stipulated and which was a definite and substantial term of her contract. In short, equity would have compelled a specific performance by the defendant, and after such performance as the subject matter was capable of had been given, the common law remedy of damages would be her sole security for the performance of the plaintiff's side of the contract. If upon April Ist Lumley refused to permit performance, the mere fact that he had previously submitted himself to the court would not have equipped the chancellor with the machinery to compel him specifically to perform. Nor, if the contract were based upon the number of actual appearances, is it easy to see how equity could determine wbat should be paid her with respect to her compliance with the negative covenants if it were claimed to have jurisdiction to try to do so. To argue that it would have any such jurisdiction, is to advance an argument which would if true comprehend every conceivable case, and so abolish the mutuality rule in toto, or leave no possible case where any enjoined defendant could be left to the sole security of an action at law, and thus totally destroy the value of the test suggested by Dean Ames.

The situation is but slightly different in the actual case of Lumley v. Wagner. The injunction there issued after the time for. affirmative performance had arrived. In the event that Miss. Wagner thereafter chose not to perform affirmatively, whatever loss she might sustain is due to her own fault, and perhaps does not justify sympathy. If, on the other hand, she should yield and perform not merely the negative but also the affirmative portions of her contract, her former threatened breach becomes res inter alios acta. What assurance has she that Lumley henceforth will perform his covenants? It is said that the moment he ceases performance the injunction will be dissolved either automatically or 
by the court.58 This is an assurance, not that he will perform his side of the contract, but merely that he will perform such portion of it as he chooses to perform. This is no assurance at all. An injunction running in one's favor is no security against one. The assumption is natural that if he has seen fit once to enjoin the defendant he will not afterward himself fail to perform. Changed circumstances, unprofitableness of the enterprise, for example, may, however, totally change his view, and at a time when defendant has become unable to make any other arrangement whatever for securing the advantages to her which would have flowed out of an actual performance of her contract. It is no reply that she seemed originally to have valued such advantages lightly, for that breach has become res inter alios, and her former breach may have been contemplated (and probably was), with a view of obtaining still greater advantages of the same type. A performance toties quoties may perhaps be assured, but such a performance was not contemplated. The contract was not divisible but was an entire one, and part performance by the plaintiff may be just as objectionable to the defendant as a total failure of performance by the defendant would be to the plaintiff. It is no answer to say that mutuality is present so long as equity's decree is in force. The point is that such mutuality of performance may lead to an unjust result and that is exactly the thing that equity adopted the mutuality rule to prevent. Perhaps the chances are so great that the plaintiff will perform that, under the circumstances, equity may take the risk. Of course that is exactly what it did in Lumley v. Wagner, but the point is to be made that in Lumley $v$. Wagner, we have a case wherein equity has decreed specific performance against the defendant, although after substantial performance "the common law remedy of damages is her sole security for the performance of the plaintiff's side of the contract." That and the security that he may choose fully to perform-which is exactly the security for actual performance that any person has in any contract that is clearly beyond equitable cognizance.

Attempting to codify these two cases into the rule, do we not find the result to be something like this:

Equity will not compel specific performance by a defendant if after performance the common law remedy of damages

58 Stocker v. Wedderburn (1857), 3 K. \& J. 393; Cincinnati Exhibition Co. v. Marsans (1914), 216 Fed. 269. 
would be his sole security for the performance of the plaintiff's side of the contract, excepting in the case of the enforcement of negative covenants in personal service contracts ${ }^{50}$ where affirmative performance by the defendant would be continuous, synchronous with, and dependent upon performance by the plaintiff; and in this case equity will enjoin a breach of the negative covenant so long as the plaintiff is not guilty of a breach of his side of the contract, Or this,

Equity will not compel specific performance by a defendant if after performance by the defendant it is either certain or probable that the defendant will have to resort to the common law remedy of damages to secure performance of the plaintiff's side of the contract.

Viewed in the light of any of the three phrasings of the rule, what effect should the inclusion of the ten-day "release" clause in the ball player's contract have upon specific performance against him? There is no greater violation of the rule suggested by Dean Ames in this case than in Lumley v. Wagner. The defendant has the security of the termination of the injunction upon non-performance by the plaintiff, whatever that may be deemed to be, as much in the one case as in the other. The case falls equally with Iumley v. Wagner within the second phrasing, for it comes explicitly within the exception. Under the third phrasing the question would be one of probabilities, of whether the "release". clause affects the requisite degree of certitude of assurance to the defendant that if he will perform the plaintiff will also. Is the probability of performance heightened, lessened, or unaffected by this provision? In a case like Lumley $v$. Wagner, discharge would be wrongful and actionable. In a case like that of American League Baseball Club of Chicago v. Chase, discharge would be rightful and non-actionable. Discharge at any rate would seen more likely to occur in the latter than in the former situation, but in the latter, discharge after ten days' notice is not non-performance. All that the player has any right to be assured of is a ten days' performance, for that is all that he has bargained for. As well require a purchaser to

50 If the conditional decree be deemed a sufficient mode of assuring plaintiff's performance, the principle seems equally as applicable to all cases involving continuous synchronous performance, as it is to personal service contracts. The earlier case of Hills v. Croll (1845), 2 Phil. 60, did not apply this method, and cases seem lacking where it has been applied since that date, other than in cases like Lumley $v$. Wagner. 
be assured of one hundred and sixty acres when he has bargained for but forty, as to assume that the player is entitled to be assured of a year's employment when he has stipulated for but ten days. The period of the player's rights being shorter under a contract containing the ten-day clause than under a contract without it, there seems to be a greater likelihood of performance by the club of what it has agreed to do with the ten-day clause included than if it had been omitted. The relatively small performance which the plaintiff must give to escape further obligation seems, as a practical matter, completely to insure performance of his side of the agreement such as it is. ${ }^{60}$

Thus it seems to follow that the present "National Agreement" contract has certainty, consideration, mutuality of obligation, all the mutuality of remedy which equity exacts in Lumley v. Wagner (which is none), and even a greater probability of mutuality of performance than in Lumley v. Wagner itself. Any other conclusion can be had only by confusing the meanings of the term "mutuality," and by confounding it with inequality of consideration. The result reached in the Chase case seems sound, but it does not rest upon any lack of mutuality in any sense which has yet been herein discussed.

There is considerable authority upon the question whether equity will specifically enforce a contract wherein one of the parties has reserved a right to terminate the agreement. If the defendant has reserved this right and has exercised it, obviously there is nothing to enforce. If he has not yet done so, but may at any time do so, even upon a condition, specific performance is refused. Equity might have ordered him to perform until he chose to exercise this condition, but this would be leaving performance to his option and be inconsistent with a peremptory command. ${ }^{61}$ If, on the other hand, the right is reserved to the plaintiff, different considerations would arise. While performance of the court's decree is in a sense left to the plaintiff's option, he is not the one against whom the court's order is directed.

${ }^{80}$ It is to be noted that the opportunity for development and public appearance, which is a real part of the consideration in the case of a singer, is hardly as important in the case of the baseball player, by reason of the fact that it is wholly in the discretion of the manager when to require the player to yield his place to a substitute while the contract is being performed.

61 Express Co. v. Railroad Co. (1878), 99 U. S. 191, 25 L. Ed. 319; Jones v. Jones (1803), 12 Ves. Jr. 186. 
The cases seem capable of classification into several groups: (I) Where the right reserved is dependent upon no condition and is immediately available; (2) When the right is so available but only upon terms; (3) Where the right may be exercised only at a future date. This date may be remote or otherwise.

In the first category there is really no mutuality of obligation. The promise is illusory because no obligation enforceable either in law or in equity is imposed upon the promisor. ${ }^{82}$ Equity should require of contracts that which a court of law would require. This seems the true explanation of cases like Taussig v. Corbin, ${ }^{63}$ Friendly v. Elwert, ${ }^{64}$ Sturgis v. Galindo, ${ }^{65}$ and Iron Age Publishing Company v. Western Union Telegraph Company. ${ }^{86}$ In the second category fall the cases of Ulrey v. Keith, ${ }^{87}$ Watford Oil \& Gas Company v. Shipman, ${ }^{68}$ and Marion County, etc., Co. v. Dykstra, ${ }^{69}$ wherein the plaintiff had the right at any time to rescind upon paying one dollar, and Glass v. Rowe, ${ }^{70}$ wherein the same right was reserved upon paying two hundred dollars. The first three of these cases present only a technical legal consideration, the last perhaps a substantial consideration, though one relatively small. In each case the court refused a specific performance. In the third category are Marble Company v. Ripley, ${ }^{71}$ where there was a right to terminate at the end of a year, Rust v. Conrad, ${ }^{72}$ where the period was thirty days, Dockstader v. Reed, ${ }^{79}$ where the period was two weeks, Metropolitan Exhibition Company v. Ward, supra, Brooklyn Baseball Club v. McGuire, supra, Wecghman v. Killifer, supra, American League Baseball Club of Chicago v. Chase, supra, and

62 Strong v. Sheffield (1895), 144 N. Y. 392, 39 N. E. 330. It cannot be said that even law courts have uniformly recognized this principle. Thus, there are cases that hold that a promise by a vendee to take all he may "want" of a certain commodity creates a binding obligation upon him. Cooper v. Lansing Wheel Co. (1892), 94 Mich. 272, 54 N. W. 39 , and even in equity there are holdings that an injunction may issue in favor of a plaintiff when he could at any time lawfully cease performance. Rolfe $v$. Rolfe (1846), $15 \mathrm{Sim}$. 88.

${ }^{63}$ (1906), 142 Fed. 660.

64 (1909), 57 Ore. 599, 105 Pac. 404.

65 (1881), 59 Cal. 28, 43 Am. Rep. 239.

66 (1888), 83 Ala. 498, 3 So. 449; and compare, Vassault v. Edwards (1872), 43 Cal. $458,462$.

o7 (1908), 237 I11. 284, 86 N. E. 696.

08 (1908), 233 I11. 9,84 N. E. 53.

69 (1911), 165 III. Ápp. 490.

70 (1891), 103 Mo. 513, 15 S. W. 334.

71 (1870), 10 Wall, 339, 19 I. Ed. 955.

72 (1882), 47 Mich. 449,11 N. W. 265.

73 (1907), 121 App. Div. 846, 106 N. Y. Supp. 795. 
Philadelphia Ball Club v. Lajoie, supra, where it was ten days. The last was the only one of these eight cases wherein an injunction issued. ${ }^{74}$ All of the seven cases are rested upon Marble Company v. Ripley, supra, or upon a case which in turn rests upon that case, excepting Dockstader v. Reed, which cites no authority. Rust v. Conrad is alleged to be supported by some partnership cases and by Express Company v. Railroad Company, supra, in which a right to terminate existed in the defendant, which is obviously a totally different matter. The opinion upon the point involved in Marble Company v. Ripley, was of the briefest character, consisting only of the conclusion stated and the quotation of a passage from Fry on Specific Performance, the writer of which cites no case upon the point and probably never had it in mind. The passage furthermore is demonstrably unsound in many particulars as to the matters to which the author was advertent, as Mr. Ames has pointed out. ${ }^{75}$

These various decisions do not discriminate between the foregoing classes of cases but lay down the universal rule that if the plaintiff has reserved a right to terminate his obligation under any circumstances, he cannot secure specific performance, on the ground that the contract "Jacks mutuality." Excepting in the first group, the contract does not lack consideration and hence there is "mutuality of obligation." In many of the cases the subject matter of the plaintiff's promise was of equitable cognizance and hence there was "mutuality of remedy" as to all that the plaintiff actually promised, and in every case as much as there was in Lum.ey v. Wagner. In each case an injunction could have been issued in the way it was in Lumley v. Wagner: that is, to terminate upon the plaintiff's failure to continue performance, so that there

74 The Chase case cites ten other cases for the same proposition: Lee v. Chicago League Baseball Club (1912), 169 Ill. App. 525; Duff v. Hopkins (1887), 33 Fed. 599; Shields v. Trammell (1857), 19 Ark. 51; Giles v. Dunbar (1902), 181 Mass. 22, 62 N. E. 985; Lawrence v. Dixey (1907), 119 App. Div. 295, 104 N. Y. Supp, 516; Levin v. Dietz (1907), 194 N. Y. 376,87 N. E. 454,20 I. R. A. (N. S.) 251; Arena Athletic Club v. McPartland (1889), 41 App. Div. 352, 58 N. Y. Supp, 477; Wadick v. Mace (1908), 191 N. Y. 1, 83 N. E. 571; Palmer v. Gould (1895), 144 N. Y. 671,39 N. E. 378; Ide v. Brown (1904), 178 N. Y. 26, $70 \mathrm{~N}$. E. 01 . None of these are in any way pertinent upon the question of the effect of a reserved right to terminate a contract, but are concerned with other phases of the mutuality rule. Perhaps in no other field of the law are cases so indiscriminately cited as they are under the head of mutuality. Much of the confusion which pervades the subject is thus occasioned.

753 Columbia Law Review, 1 
was at least the same assurance of "mutuality of performance" as in Lumley v. Wagner. What kind of mutuality therefore is lacking?

In the case of Philadelphia Ball Club vs. Lajoie, supra, the court used the following langnage:

"We cannot agree that mutuality of remedy requires that each party should have precisely the same remedy, either in form, effect, or extent. In a fair and reasonable contract it ought to be sufficient that each party has the possibility of compelling the performance of the promises which were mutually agreed upon. Mere difference in the rights stipulated for does not destroy mutuality of remedy. .... Why should not a court of equity protect such an agreement until it is terminated? .... The defendant has the possibility of enforcing all the rights for which he stipulated in the agreement, which is all that he can reasonably ask. Furthermore, owing to the peculiar nature and circumstances of the business the reservation upon the part of the plaintiff to terminate upon short notice does not make the whole contract inequitable."

The case cites Singer Sewing Machine Company v. Union Buttonhole and Embroidery Company, ${ }^{76}$ wherein it was conceded that the plaintiff had the right to terminate the contract on notice. The court there, nevertheless, issued an injunction, saying:

"Everything must depend upon the nature and circumstances of the business. It is certainly competent to the parties to make a contract which will be equitable and reasonable and in which their rights ought to be protected while they last, though it may be terminable by various circumstances, and though one party may have the sole right to terminate it, provided their stipulation is not one that makes the whole contract inequitable. .... If the defendants for valuable consideration have given the complainant an exclusive license until he forfeits it, I do not see why a court of equity should not protect. that license by an injunction as usual so long as it is not forfeited."

Although it is a little difficult to see from the facts reported what absolute consideration there was to the contract on the part of the plaintiff, it is noticeable that the court considers the contract to have been based upon a valuable consideration. These two cases, therefore, distinctly recognize the principle that an injunction may issue in behalf of a plaintiff, notwithstanding his

76 (1873), Fed. Cas. No. 12904. 
reservation of a right to terminate the contract. Whether the rule was correctly applied or not in these two cases, is not the test therein suggested the real one-that is, whether the contract as a whole is equitable?

Equity has refused to enforce unconscionable contracts, ${ }^{77}$ those productive of hardship, ${ }^{78}$ those executed under duress, ${ }^{79}$ and those founded upon consideration so slight as to "shock the conscience of the chancellor." 80 It is not enough that the consideration is merely inadequate, ${ }^{81}$ but when the consideration approaches the vanishing point equity does take that fact into account, at least, in modern cases, in connection with other inequitable circuinstances. The solution of an equitable problem requires an examination of all the complex of elements involved. There is no reason per se for non-enforcement in the mere fact that the plaintiff may rightfully terminate the contract. Such an act is not in disregard of the court, nor is enforcement necessarily a "vain thing." The court is not usually concerned if a complainant chooses to waive a part of his legal rights. Why should it be here? It is inconceivable that a court would not decree the specific performance of a lease for eleven years, with an option to the plaintiff to terminate it at the end of the tenth year, ${ }^{82}$ and yet that result would necessarily follow from the reasoning in the Chase case, and in most of the authorities cited by it.

However, when a right to terminate the contract is reserved to the plaintiff and may be exercised in such a way that hardship may result to the defendant, or if termination by the plaintiff may be had in such a way that the absolute consideration which the defendant is legally entitled to demand may be entirely noninal, equity may refuse to interfere because the situation may be thus generally inequitable. In the first category of cases ${ }^{88}$ there will thus be no specific performance because there is no consideration

77 Friend v. Lamb (1893), 152 Pa. 529, 25 Atl. 577, 34 Am. St. Rep. 672 .

78 Nickels v. Hancock (1855), 7 DeG., M. \& G. 300.

79 Dewar v. Elliott (1824), 2 I. J. Ch. 60, 178.

80 Coles v. Trecothick (1804), 9 Ves. Jr. 246; Thayer v. Younge (1882), 86 Ind. 259.

81 Burrowes v. Locke (1805), 10 Ves. Jr. 470; Ready v. Noakes (1878), 29 N. J. Eq. 497. The result otherwise in California is due to statute, Cal. Civ. Code, $\$ 3391$.

82 Powell v. Smith (1872), 14 Eq. 85.

88 Supra, n. 62. 
at all. In the second category the terms upon which the plaintiff has the right to cease performance may assure the defendant a valuable consideration, or merely a nominal one, or one relatively small. The relative inadequacy of consideration is important along with the nature of the subject matter of the contract, the situation of the parties and the probable effect of enforcement in determining whether or not the situation is one of general equitable cognizance. In the third category the question of fairness of consideration turns upon the length of time which must intervene before the plaintiff can exercise his right of termination, and hence upon how much of consideration is absolutely secured to the defendant. A right to terminate on twenty-four hours' notice furnishes scarcely more consideration than such a right upon payment of one dollar. A right to terminate only after the expiration of a year assures the defendant of an adequate consideration from the plaintiff. The case is like that of a contract for the shorter period, with an option for the balance of the longer period. A contract in this last form certainly would be enforceable.

The baseball contract falls between the two extremes, but much nearer the nominal end of the sequence than to the end that assures consideration. The club exacts much from the player and in return assures to him very little. In addition to this disparity in the considerations proceeding from the two sides, are the facts that under the "national agreement" the situation of the parties is not one assuring entire freedom of contract, and that a discontinuance of performance by the club may come at such a time as to operate as a hardship upon the defendant by reason of the peculiar type of market that exists for his services. ${ }^{84}$ Under these circumstances it may well be doubted where the plaintiff's case as a whole is one justifying equitable interposition. ${ }^{85}$

In Weeghman v. Killifer, supra, a further and novel question was presented. The player in I9I3 had signed a contract containing the release clause, and a reserve clause which left the salary for the year of IgI4 entirely to subsequent agreement. In January, 19I4, he entered into a contract with the plaintiffs which con-

84 In the Lajoie case, the court thought that business conditions justified such a contract. This may well be doubted under the conditions of the employment that now prevail.

${ }^{85}$ Lack of "mutuality" in this seventh sense seems to mean inadequacy of consideration, plus unequal position. The court also calls this a "unilateral" contract. The discussion will have shown, if nothing else, the great need in the law of a precise scientific terminology. 
tained neither of these clauses. On January 2oth he, however, repudiated this second contract and returned to his former allegiance. An injunction was sought by the employer under the second contract and thus not under but against the contract which was objectionable. An injunction was refused upon the ground that as the plaintiff knew of the facts and terms of the defendant's prior contract at the time that he employed him, he did not come into equity with clean hands. The court says that by reason of the reserve clause the agreement of 1913 was "nothing more than a contract to make a contract if the parties then could agree to contract" and hence not actionable at law or in equity. It considered, however, that the player was guilty of a moral if not a legal wrong against the first club. The court speaks of both the plaintiff and the player as having "acted wrongfully and in bad faith." It is a novel idea that a man who has executed a contract nowhere legally enforceable against him, yet owes a moral duty of performance according to its terms.

Lumley v. Gye, ${ }^{86}$ held that the rival manager who induced Miss Wagner to break her contract had thereby committed a tort against Lumley. In Walker v. Cronin, ${ }^{87}$ it was held that it was equally a tort to induce a servant at will to leave his master. The idea, too, is found in many places in the law that he commits a tort who without legal excuse interferes with what Lord Ellenborough ${ }^{88}$ called a "probable expectancy." 89 The proposition, therefore, that the plaintiff in hiring away an employe under a contract not legally enforceable but which probably would have been performed, thereby did an act which deprived him of an equitable status, is thus much more plausible than the theory that the player committed an equitable wrong by asserting a legal right. The court's position would seem unquestionably sound ${ }^{\text {oo }}$ if the reserve clause had been of the definite type found in the Chase case, for thereby a contract for I9I4, enforceable at law if not

${ }^{86}$ (1853), 2 E1. \& B. 216.

87 (1871), 107 Mass. 555.

${ }^{88}$ See Jersey City Printing Co. v. Cassidy (1902), 63 N. J. Eq. 759, 53 At1. 230 .

${ }^{89}$ See Ames \& Smith's Cases on Torts, chap. VI.

90 Unless we assume the correctness of the statement in the Chase case, that the whole contract is illegal at common law as tending to create a monopoly. 
specifically in equity, would have been created between the player and the first club. The mere fact that by reason of administrative rules of equity, specific performance could not have been obtained, would not have been material.

Berkeley, California.

Barry Gilbext. 